\title{
Liberalism's All-inclusive Promise of Freedom and its Illiberal Effects: A Critique of the Concept of Globalization
}

\begin{abstract}
The narrative of globalization is twofold: it refers to the hope for the export of democratic state forms and values from the Western world to the states of the so-called global south; it also refers to the aim of worldwide economic growth and extension of capitalist ways of production and consumption. But paradigmatic cases of action of democratic liberal states in international politics throw a twilight on this double hope. In certain cases, aggressive interventions of Western democratic states are legitimized using precisely the norms of non-intervention that claim universal validity, but turn out to follow an agenda of particular interests of economy and power. This article argues that these universal norms are not contingently transgressed, but in light of the second paradigm of globalization-of the economic spread of market relations-the process of self-constitution of democratic states here takes not a self-limiting, but an aggressive and exclusive turn. In addition, the so-called 'new wars' and 'failed states' (apparently opposing phenomena to the international agency of democratic and liberal Western states) show surprising parallels to late modern democratic liberal society. The 'management of fear' typical of these political situations aims at a regularization, through internalized habits and attitudes, of the population-including their agreement to the terror regime. In light of these considerations, the relationship between the aims of global growth and global democratization seems highly ambiguous.
\end{abstract}

It is considered to be a distinguishing mark of modern and democratic societies that they limit the use of violence by the state as a means to enforce its authority. Deliberative processes, practices and institutions limit and control as self-government the exercise of the monopoly of power of the state. Thus, democratic government is a continuing self-constitution. Violence/power is used only as counter-violence outwards to defend against outer threats-a use that is in turn controlled by the governmental measuring of its proportionality.

The narrative of globalization claims, on the one hand, the substitution of this dichotomy of outside and inside with an extension of the intrastate nonvio-

Constanze Demuth, Technische Universität Dresden (TUD)

Ә OpenAccess. (c) 2018 Constanze Demuth, published by De Gruyter. (cc))BY-NC-ND This work is licensed under the Creative Commons Attribution-NonCommercial-NoDerivatives 4.0 License.

https://doi.org/10.1515/9783110492415-006 
lent structures, resulting in an increasingly peaceful cooperation of democratic states. On the other hand, it also refers to the spread of capitalist forms of production to a 'world market' and the connected economic regulation of social order beyond the borders of nation states. This view is not without a teleology -in fact, it postulates a progress of the political structures of the world including the global south, directed towards peaceful and evermore rational forms of organization of capitalist democracies.

Nevertheless, there are political phenomena which invite us to question this apparently evident narrative, especially in the periphery of the core states of democratic liberalism. They prove wrong the assumption that prosperity and democracy for all are the beckoning aim of the global integration of economies; as if the realization of this aim posed only minor applicatory problems, which could be easily overcome. For these cases show the acceptance and relevance of national borders diminishing without the expected result of peaceful cosmopolitism. Instead, relations of power spread, are restructured and newly established; the disadvantage of the global south deepened and not remedied.

\section{A sketch of a critique of theories of democratic peace}

In order to investigate this thesis further, let's start with a critical look at the basic assumptions of the so-called 'theory of democratic peace' (Geis / Müller / Schörnig 2010). According to this theory, the liberal states have incorporated higher normative demands-specifically norms claiming universal validitythan undemocratic states. They internationally codified these norms, for instance in International Humanitarian Law. The theory of democratic peace doubles this observation with a hypothesis: that democratic states, with their ambitious ideals of human rights and universal values, fight fewer wars than undemocratic ones.

Different authors, such as Yves Winter, Anna Geis, Oliver Eberl and others, have shown that this correlation doesn't hold up to the test. In fact, democratic states fight fewer wars with other democratic states, but more wars with undemocratic ones, and in total about the same amount. In addition and maybe even more significantly, the standards of conduct of war of the former (for instance, with regard to the protection of civilians or of prisoners of war) are not higher; that is, the legal, respectively moral commitment to universal norms neither improves the quality nor the quantity of military conduct of democratic states. 
How can we account for the failure of this hypothesis? Without a doubt, principles that claim universal validity are the mirror of everyday life of the Western world, which incorporates the respect of the other as other into its practices. It is increasingly transformed into the political structures and institutions of liberal and democratic states. The codified and institutionalized ideal of the participation and respect of everybody, including the marginalized and minoritized, requires the ongoing democratic process of self-constitution of the community as community. This process takes place in practices of the deliberation and participation of potentially everybody. This normative commitment to processual allinclusion has, by definition, global applicability. Internationally, this claim finds its codification in the principle of non-intervention of International Humanitarian Law.

But the normative level is not only (as theories of democratic peace claim) guiding for an increasing degree and extension of global democratization and peaceful cooperation. It is precisely the incorporation of universal claims that creates a new function of legitimatizing aggression against non-democratic states. Liberalism has an aggressive aspect that annuls precisely these standards, even while invoking them. Oliver Eberl even spots a 'new liberal antipluralism' (Eberl 2016, p. 364, my transl.). He considers it as a successor of Christianization and colonization.

Internationally, the democratic practice of self-constitution is mediated by the construction of an image of the undemocratic other, irrational and dangerous. This construction works by the utilization and, at the same time, transgression of norms with universal claims (such as the abovementioned International Humanitarian Law of non-intervention). These are reformulated and transformed into an instrument of rule and power. The reconstitution and self-affirmation of the Western states as democratic here takes place precisely through this exclusion. The history of the term 'rogue state', coined by George W. Bush, exemplifies how the pretext of protective motives according to international laws can be turned into a function of the enforcement of power interests.

Indeed, the acceptance and relevance of national borders is decreasing under the democratic pretext of the increase of processual self-government. But this democratic stance is coupled with the conception of a peaceful, global economic cooperation launched by the democratic states of the Western world. This second aspect transforms the very meaning of the processual reconstitution of liberal states. The result is a paradigm of cooperation in the terms of market rationality that raises doubts about the presumed effect of democratization and extension of nonviolent relations of globalization. Globalization, here, turns out not to lead to increasingly homogenous cosmopolitanism via all-inclusive political practices. For the universal norms that correspond to the democratic princi- 
ple are utilized as a legitimization of exclusion, oppression and violence motivated by vested interests that they help to veil.

The incorporation of these universal principles into the political structures and institutions of liberal and democratic states brings about its own tendency to repress and oppress, which has to be reflected and criticized. In late capitalism, the economistic interpretation of the democratic ideals of equality and participation of all is a very influential one. Thus, the fight for power on the one hand and the fight for legitimization on the other become blurred. The claim to all-inclusion implies here the utilization of the contribution of all and its own radicalized exclusion. Whatever is detracted from this utilization is excluded; it is first imagined as wholly other, and is then imagined on all conceptual levels to be excluded from humanity and rationality as such. This creates the impossibility of the conception of individual and collective 'agents' to whom the rules of armed conflict and the right to autonomous self-government do not apply.

\section{'New Wars' and 'Failed States'-cases of dysfunctional state capacity or extreme examples of neoliberal forms of regulation?}

I now want to take a look at the so-called 'New Wars' and their relation to globalization. New Wars are usually considered as a peripheral phenomenon of the globalized world-a form of war activity turned completely irregular. Theories of international politics tend to depict these phenomena as dysfunctional exceptions in contrast to the democratic state capacity with ambitious norms. But this account overlooks or even veils the exemplary character of New Wars within the organization of an increasingly globalized late modern world. They don't establish chaotic violence as opposed to the political organization within the clear borders of nation states. Rather, again, the fight for power on the one hand, and the fight for legitimization on the other become blurred-and this entanglement proves to be a specifically late modern condition in a globalized world.

Authors such as Mary Kaldor or Herfried Münkler draw a clear line between the New Wars and interstate wars. Presumably, these new forms of conflict occur from the beginning under the radar of International Humanitarian Law of armed conflicts, since they do not limit themselves to classic military action. These new forms, according to the authors, are constituted by an "indirect war conduct, where the use of traditional military means and the use of political strategies merge. In addition, excessive and broadly spread violence occurs whose agents 
are mainly private entrepreneurs of war with economic interests." (Münkler 2002, p. 7, my transl.) According to the authors, the reason for this restructuring of armed conflict is an internal lack of function of state capacity concerning law and state apparatus. This lack of function is in contrast to the functioning of regular state force in Western states. The latter are affected by this development only derivatively: they suffer from an export of globalization by the destabilized regions in the opposite direction, which transports chaos and amorality in the form of terrorism.

But this opposition is not as convincing as it seems at first glance. Key to the critique is the following observation: the combination of forms of violence with political strategies of conviction is a form of war not only against the population, but also to win the population. In this respect, it is the equivalent of neoliberal rule. Thus, the conventional military conflict steps back and is replaced in the New Wars by a 'management of fear' exercised on the natives, which continually and excessively terrorizes them, economically exploits them and psychologically forms them into allies. This form of terror is neither acceptable under the rules of war conduct of international law, nor does it follow rules of economical and appropriate use of violence. It is nevertheless highly effective. Yves Winter comments on this entanglement of a militarization of politics and a politicization of war under the economic paradigm:

The battle of decision is replaced by the massacre and by a systematic sexual violence which are used as instruments of fear management. [...] The disestablishment of war undermines the limits of international law and initiates an era of commercialization of violence with private entrepreneurs of war, warlords and international mercenary companies. War becomes a form of life. (Winter 2008, p. 54)

This 'form of life' is marked not by the fading of state control, but by the blurring of state control and state dysfunction-of deregulated forms of economy and 'regulated' enforcement of the interests of global companies. It is far from ineffective and follows its own rationality.

This specific structure is also typical for so-called 'failed states' like Mexico. From the perspective of Western democracies (which international political theory usually assumes), the nationwide influence of drug cartels appears as the powerlessness of the state. The cartels preclude resistance against their criminal activities by means of organized murder, blackmail and rape. But this apparently apolitical violence spreads even further: independent journalists, trade unionists and representatives of indigenous people who act as opponents of capitalist forms of privatization, land robbery and exploitation become victims of atrocities as well. This terror is used to enforce the interests of politically and economically influential groups, without the intervention of the control of the state ex- 
ecutive. Paramilitary groups act as private armies of great landowners (Zelik 2009, p. 205-206). Activities of cartels are supported, protected and veiled by police actions and politically motivated assaults. The different groups of agents become more and more indistinguishable.

Eventually, in this situation in Mexico, the population have formed armed militias. Initially, they try to replace the lost monopoly of power of the state and resist the attacks of drug cartels organized paramilitarily. But their procedures of self-justice themselves become quickly delimited, irregular and economically corrupted, assimilating to the forms of actions of the original agents of excessive violence. (The documentary Cartel Land by Matthew Heinemann follows this development.)

That is, in New Wars and 'failed states', the population becomes both victim and agent of violence; it is formed by and takes over the maintenance of the structures of transgression. This is not accurately conceived of as an opposition between destabilized state government on the one hand and boundless organized crime and private agents of violence on the other hand (the latter making use of the gap of order). Rather, the entanglement of economic interests, government interests and entrepreneurship of violence achieves thorough stability in a regime of violence and forms the population into its participants and supporters.

Authors such as Münkler depict this situation as contingent and theatricalize it. A case in point is the figure of the southern warlord, who appears in Münkler's account as the emblematic Other of state-ruled order. Diefenbach critically takes this depiction to an extreme: "There he is: de-limited, de-disciplined, corrupted by money and pop culture [...]-a monstrous irregular killing machine.” (Diefenbach 2003, p. 186, my transl.) This theatricalized image veils the fact that this state of affairs is not a contingent failure of state rule, but a necessarily occurring symptom. It is the symptom of the entanglement of universal claims of freedom and equality on the one hand and of the paradigm of market rationality on the other. The consequence of this entanglement is a particular structure of the development and implementation of habits and ways of action-turning the civil population into a resource that continually needs to be worked on by shaping and transgressing their form of life. It needs to be permanently formed and coaxed into practical compliance, and to achieve this aim terror (or 'fear management') is not an irrational monstrosity, but precisely rational.

Classic theories such as Münkler's assume that 'failed states' and the New Wars are phenomena of state collapse that are not only geographically but also conceptually peripheral. According to them, the source of these developments is that state institutions lose their monopoly of violence including the power to protect their citizens. In fact, this loss of power is radically ambivalent: the monopoly of violence of private war entrepreneurs weakens the state out- 
wards. At the same time, these proxies push state interests. It is a kind of irregular regulation by violence, in which the state suffers from and profits from its own weakness (Zelik 2009). For governments thus don't have to face the problems of legitimation, neither with regard to the violent means the proxies use nor with regard to the aims thus furthered. In Mexico, this is the case, for instance with regard to the capitalist opening of markets and the privatization of common goods connected to land robbery, which thus become available to global capital investors after native peasants are violently dispossessed.

By now, this structure of excessive violence appears not as an opposite to the functioning state capacity; rather, it appears as exemplary of the principles of neoliberal organization, insofar as it is a government aiming at self-government. The population subjected to these conditions also acts as their agents. It is an extensive, all-present, inner political police-regulation, which integrates methods of convincing and questions of legitimacy into processes of incorporating compliant forms of practice. The excessive violence is an effective means for this subject formation. Therefore, it assumes both liberating and dispossessing traits. Military power mingles with traits of police violence, managing of health care and the control of secret services. Their joint activities record all details of life, regulate and form them. As a training of the population it is at the same time an economical government, since it assigns the work of disciplining to the subjects themselves. These aspects seem contradictory, but they turn into the condition of each other.

Authors such as Zelik (see also Winter 2008; Comaroff / Comaroff 2012) claim a special relevance for these phenomena of delimited violence in our increasingly global, liberal world. They assume that the developments in the socalled periphery of the core states of democratic liberalism point to a constitutive aspect of globalization and its entanglement of democratic politic organization, open markets and deregulation.

This development is often accounted for in very positive terms. Its down side becomes apparent in the New Wars and so-called 'failed states'. That is, to depict the supposedly enlightened core countries of liberalism as 'stable' and committed to universal rights for humans and people is already one-sided. This result yields the following suspicion: the rule with instability and contingency is precisely typical for the neoliberal shaping of societies and its claim on the individual. It forms the individual to conceive of her- or himself as 'entrepreneur of himself' (Bröckling 2007, my transl.) and to act accordingly.

Thus, the central question turns out to be how exactly the phenomena described so far connect to the globalization development of the world and the West in particular-to those developments we are used to seeing as gains of freedom and political liberalization. 


\section{Governing with security according to Foucault as a type of judgment}

The narrative of globalization assumes a historical development from the nation state (which increasingly limits and controls state violence, but executes it outwards) towards global, democratic cooperation. The consequences of globalization are, according to the narrative, global relations of peaceful and egalitarian cooperation in economy and politics. The corresponding loss of relevance of local forms of government and of nation states to transregional democratic political structures appears as unquestionable gain of freedom and progress.

Without a doubt, it is accurate to see this development as a story of emancipation from historically specific forms of ruling and tradition. But to uncritically read it within the mentioned frame of a narrative of globalization is to fall victim to an ideology. On the one hand, this history of emancipation is by no means the history of a progress without setbacks in terms of peaceful and free cooperation. It is in fact a history of emancipation of people and minorities who increasingly could (and had to) fight for their own voice and political representation. On the other hand, there is the implied equation of an ongoing spreading of democratic state forms with a spreading of economically liberal state forms. In fact, the increasing overlap of these two levels (the political and the economic) not only results in post-democratic signs of fatigue like new nationalisms, which can be witnessed in all Europe-it also leads to a form of illiberal rule of its own which finds its current extreme but paradigmatic manifestation in the New Wars and 'failed states'.

The work of Michel Foucault describes the development of rule, law and norms becoming more and more immanent within the society of late modernity. He is highly critical in his evaluation of this development against the framework of the increasing entanglement of politics and economy. Many phenomena of the by now globalized world disclose themselves particularly clearly in light of Foucault's critical observations of the ever more self-limiting and self-delimiting liberal society of late modernity. Correspondingly, a lot of authors by now adopt this frame of interpretation (such as the aforementioned Opitz, Winter, Eberl and others). I will now briefly explore the ways in which Foucault's theory of governmentality seems to be a useful tool to analyze developments of globalization.

Neoliberal governing is not without ambivalence, as neoliberalism's account of itself suggests. Indeed, its landmark theme is the restriction of state intervention. But it has a dubitable successor: the organization and operationalization by the judgment and calculation of reality. This approach is far from the apparently 
objective and neutral accounting, but is constitutively the continual transgression of rules and rights set so far. That is the case, since it always sets its own standards with its actions.

According to Foucault, characteristic of this structure of overcoming rules and structures is the paradigm of security; the model of it is police action. The 'police government' of social processes creates one state of exception after the other. It is "the permanent state of exception, which proceeds in the name and in dependence of the principles of its own rationality without being based upon the rules of law." (Foucault 2004, GG I, p. 488, my transl.) This characterization shows an uncanny resemblance to the terror management carved out as typical for the New Wars and 'failed states' before it.

A faculty of judgment that is shaped by police action and bureaucracy appears in correspondence to a government of in-security. It rules via sub-legal techniques and thus enacts and provisions every detail of social life. It counts with insecurity insofar as it works with a non-codified situational knowledge, which is formed out of and applied to precisely these details of everyday life and its subjects. It is thus always working on its own limit; that is, it is always integrating it.

With respect to the political subjects, this structure is democratic, because it takes into account everybody and turns everybody into an agent of this accumulation of knowledge. But at the same time, this concept of equality shapes it as an economic equality of market agents. This paradigm of the organization of society is characterized by an interplay between discourses and practices. Knowledge production identifies dangers and develops forms to react to them in ways of conduct. These ways of conduct form the material of an ongoing investigation by these discourses and of a continuous regulation. Society's agents now have to turn all their ways of being and their prospects into valuable goods for the refinement of regulation. The regulation of conduct aims at a normalization of the totality of our ways of being. In fact, this aim appears to be just technical, but it is thus veiled, naturalized and its normative, political dimension is concealed (Meyer 2009, p. 29).

For within this paradigm, the 'freedom of all' takes on a peculiar meaning. It is the freedom of all subjects who realize their own possibilities to full capacity as subjects of their own self-management and self-interpretations of the market of life scripts and symbolic value. This corresponds to a radical disenfranchisement of the subject who doesn't conform to this market organization. On the one hand, the very emphasis on everyday forms of life and the formulation of common understandings of selves has an aspect of (democratic) generalizations and democratic equality. But on the other hand, this formulation and formation here takes on the shape of a practice of dominion. 
Though the calculating with constructions of danger seems, according to liberal ideology, maximally self-limiting, it is illiberal at the core. It is self-limiting and self-delimiting, since it proceeds by forming its own legitimation and object. Its calculation registers 'reality' first of all, as a potential and as a virtuality-and at the same moment, it reduces and calculates it. The procedures measure everybody and the future possibilities emanating from their conduct as surplus value, and enforces them to realize this future potential. It is thus a calculation of profit and a calculation of risk that binds as if it had factual and normative power.

According to Ulrich Beck's theory of risks, social risks de facto have increased exponentially. Supposedly, these risks are barely to be anticipated and accounted for (Beck 2007). In contrast, François Ewald considers the contemporary attempts to determine and keep in check a potential danger as a play with the imaginary. It doesn't aim at a control of the given, but at a certain way of constituting the other and, therewith, one's own (Ewald 1993). This achievement construes the world by reacting to it with adapting institutional forms; that is, it is inherently self-exceeding. This order-transgressing ordering is a 'political strategy' in the broader sense, precisely since the entanglement of constitution and depiction in this world figuring activity is concealed by a positivist selfimage of natural science.

A case in point is the means of automatic face detection. It speaks of this entanglement of universal norms turned into institutions on the one hand and, on the other, of a regulation of the life world according to statistical calculus. At the core of it lies an emphasis on the permanent adaption of practice rules guided by their limit: the potential and upcoming. It obliges anticipation and prevention; that is, to register not particular subjects according to fixed attributes, but all subjects according to their unrealized potential. This consideration supplies the means to then classify all and everyone according to their utilizability. In case of doubt (i.e., in the border case of non-calculability or nonutilizability necessary to this method), it figures them and treats them as monstrous threats. According to Sven Opitz, this means is an 'imaginary technology' that grasps the Other and constitutes it as an 'amorphous, fetishized Other' (Opitz 2008, p. 223-224, my transl.).

Within this apparently liberal frame, the self-development of the individual is considered at the same time as his or her participation in the social totality. That is, just by 'going on', a person develops the possibilities and ways of life of the whole, and the knowledge of it. It thereby affirms and stabilizes this totality. This convergence turns the contingencies of the particular situation and its outcome into the material of the regulating operation that constitutes the order as such. What is yet unaccounted for is its limit and condition of possibility. It is this limit which here needs to be always constructed and thus integrated; 
as far as it stays unattained, it is to be controlled and violently mastered as a monstrous threat. This technique of government as a matter of principle even allows the exclusion of individuals from the protection of human rights-as the case of the human rights violations in Guantanamo showed (see Butler 2004, on the emblematic relevance of this political 'state of exception'). These exclusions, using the techniques of torture, rape and murder, signify a transgression of universal norms by democratic government executives of state power-norms that are by definition non-tradable and non-negotiable. But, as Butler has shown, this is within this paradigm a 'constitutive' transgression (Butler 2004, p. $50-51)$.

In question is precisely an appeal to the highest, universal norms, which at present have to become practical in institutional forms. This requires their interpretation and transgression over and over again. The semblance of presumably endangered rights of protection and freedom that necessarily accompanies this process is then used to legitimize precisely their most blatant violation: the paradigm of social interaction of peaceful, market-shaped cooperation makes a productive handling of dissent and conflict impossible-for it is accompanied by a Hobbesian, omnipresent assumption of the danger of the lapse of these interactions into a fight of all against all. This assumption is quite literally formulated in the metaphor of war prominent in public discourse in the US in regard to all aspects of social life (Winter 2008, p. 70).

This rhetoric of danger lowers the acceptable standards for a breach of law in all areas. It legitimizes the decentering and delimiting of practices and considerations of security in favor of an increasing integration into the chain of consumption of goods. Potentially risky subjects are identified and their behavior anticipated, and a-human identities are thus not only registered, but presupposed and first of all constructed. It is a calculation of the cost of freedom, which constitutes the Other as un-economic and irrational (Opitz 2008, p. $223-224)$.

In this frame of thought, the protection of the population necessitates not first of all military measures directed outwards, but police regulation and practices of knowledge directed inwards. Security is considered a scarce good. Against appearances, further demand for this good, which is offered by different, increasingly private providers, is precisely and ceaselessly created. For it is not a lack of functioning, but a necessary aspect of this paradigm that a subjective feeling of insecurity needs to be increased further and further, and thus the product 'security' is more and more in demand. In fact, the limit of the current shape of society is its working task, always aiming at a potentially global scope. 


\section{Singularity as a commodity and the possibility of emancipation}

It is precisely the overlap of juridical, moral, economic and epistemic aspects within the ongoing self-construction of the social whole that creates a violence at the core of the liberal society itself. For it is potentially global only as a structure further and further integrating and exploiting its own limits. Evidently, this fact concerns the organization of economy itself, but more radically, it concerns all forms of individual activity as self-realization, including the activity of democratic, political deliberation. Within these forms of democratic participation, everybody is supposed to be able to contribute to the shaping of the democratic society. But at the same time, in the course of neoliberal progress, these forms themselves are economized and thus exclude precisely the individual as such, as irreducible and unaccountable, which they are supposed to express. It is this unaccountability of the individual itself that is now turned into a source of profit.

The ideal of a spirited democracy is the idea of a community that develops norms and forms of life in its course, by the activity and participation of all of its free subjects, and realizes them consensually. This idea is conceived here under the paradigm of freedom shaped as self-interested self-government according to a calculation of costs. Thus, each and every subject, in all their speeches and actions, works to continually transform and shape precisely their own unaccountability as individuals into a productive, functioning social unity.

Late modern civic life is characterized by gains of freedom that have to be analyzed and acknowledged as such. But neoliberal logic not only requires the minimization of state intervention in social processes and structures-it also models these processes and structures thoroughly after the model of the market. Even political deliberation and civic engagement are pictured as calculations of contingencies that are considered as potentials of profit. This calculus is illiberal at the core, not just contingently at the periphery (Opitz 2008, p. 223). For it declares difference, conflict and social fights to be at the outer zone of democratic society in need of control. Thus, Balibar points to the "irreducibility of the phenomenon of extreme violence as a structural determinant of capitalism" (Balibar 2001, col. 1287, my transl., highlighting orig.).

Late modernity values the individual 'as him- or herself', not due to rights which are owed to class membership, tradition and privileges. This is the result of a far-reaching implementation of universal claims of freedom and of a democratic sphere of civic interaction and discourse. However, it is precisely this individual freedom to shape one's own life that is defined, utilized and ruled in 
this form of regime. Neoliberalism designs a model of humanity which pictures the individual as rational and singular only insofar as he or she contributes to and affirms the social whole by adding one more utilizable possibility to it. He or she has to follow the logic of the market in the realization of his or her individual and societal possibilities. Otherwise he or she is pictured as a violent, irrational monstrosity.

Paradoxically, it is precisely the individuality of identities and life scripts that turns into a material of integration, affirmation and processes of stabilization. Any activity-even giving and taking arguments, contesting and resisting -is seen as a practical design of meaning. Figured in this way, whatever an individual undertakes is always productive and 'value creating' insofar as it is read within and creates new patterns and forms of life to be read and understood. To realize oneself is at the same time a process of creating rules and designs of one's own and of shaping new general forms of human identity and conduct. This dimension of any activity-at once individualizing and generalizing-now constitutes a necessary effect that works as the affirmation of the structures of society and as its own integration. On the other hand, these effects pose a permanent threat to a society conceived as such.

The legitimation of the hegemony of neoliberalism consists in the promise of freedom to participate offered to everyone under the conditions of a world society. It has been argued that this promise has not been fulfilled, at least for the population of the global South, which has been subjected to massive violence and impoverishment. But the problem of the economization of all areas and democratic procedures in neoliberalism is not restricted to the periphery. Neoliberalism is constitutively illiberal, for what is at stake here is always the representation and depiction of the individual and groups in an ongoing construction of both identities and a consensus of social forces. But at the end of the day, this is not modeled as peaceful and liberal, but as forcefully integrating.

What is at stake here is a concept of unrestricted judgment and freedom of radical democratization, which is distorted into the normalization of precisely this faculty of judgment by itself. Judith Butler points to this problem as the late modern 'ghostly' creation of rules always to be adapted by a 'managerial power'. What is at stake are "rules that are not binding by virtue of established law or modes of legitimation, but fully discretionary, even arbitrary, wielded by officials who interpret them unilaterally and decide the condition and form of their invocation." (Butler 2004, p.62)

Through this lens, the situation of the late modern subject appears as radically disenfranchised precisely in communal processes of deliberation. Its only perspective on itself as capable of free judgment beyond the demand for conformity seems to be completely irrational and excessively violent. But it is pre- 
cisely this supposedly amorphous subject that points to the manifold of human life scripts as irreducible to calculation. Balibar calls it the 'non human' and 'all too human': "but taken together (and they certainly do not form a tout, an 'all' or a 'whole'), all these singularities are the majority, the quasi-totality of mankind." (Balibar 2012, p. 226)

This critique opens up a new meaning of globalization and, at the same time, of the concept of a 'human right'. A 'Human right' now appears as the right to a receptive acknowledgment of difference. The idea of cosmopolitan interaction gives up the paradigm of cooperation in favor of a conception of the other as withdrawn, never grasped and determined. In fact, it shows the need for the interruption of the activity of a continuing world interpretation and practice. This interruption reveals another figure of practice as requiring the bearing of dissent and of confrontations.

Instead of deliberating and calculating as a basis of human practice and interaction, this conception of 'self-determination against oneself' implies a critique as the renouncement and interruption of one's habitual ways of acting and judging. Foucault coins the concept of "the art of not being governed or, better, the art of not being governed like that and at that cost” (Foucault 1997, p. 29). This account allows a development of a concept of globalization and a practice of it in which freedom figures as contra-dominion-not as a cooperation of potentially all under the same calculus, but as an endurance of incomprehension and even of aversion against the other.

\section{Bibliography}

Balibar, Etienne (2001): “Gewalt”. In: Wolfgang Fritz Haug (Ed.): Historisch-kritisches Wörterbuch des Marxismus, vol. 5. Hamburg: Argument Verlag, pp. 694-696, col. 1270-1308.

Balibar, Etienne (2012): “Civic Universalism and Its Internal Exclusions: The Issue of Anthropological Difference”. In: boundary 2, 39:1, pp. 207-229.

Bröckling, Ulrich (2007): Das unternehmerische Selbst. Soziologie einer Subjektivierungsform. Berlin: Suhrkamp Verlag.

Beck, Ulrich (2007): Weltrisikogesellschaft. Auf der Suche nach der verlorenen Sicherheit. Frankfurt am Main: Suhrkamp Verlag.

Butler, Judith (2004): Precarious Life: The Power of Mourning and Violence. London, New York: Verso.

Comaroff, Jean / Comaroff, John L. (2012): Der Süden als Vorreiter der Globalisierung. Neue postkoloniale Perspektiven. Frankfurt am Main: Campus Verlag.

Diefenbach, Katja (2003): “Just War. Neue Formen des Krieges. Polizeirecht, Lager, Ausnahmezustand”. In: Becker, J. / Lanz, S. (Eds.): Space // Troubles. Jenseits des guten 
Regierens: Schattenglobalisierung, Gewaltkonflikte und städtisches Leben. Frankfurt am Main: b-books, pp. 179-195.

Eberl, Oliver (2016): “Zwischen Zivilisierung und Demokratisierung. Die Exklusion der

‘Anderen’ im liberalen Völkerrecht”. In: Soziale Systeme 14 (2), pp. 349-369.

Ewald, François (1993): Der Vorsorgestaat. Frankfurt am Main: Suhrkamp Verlag.

Foucault, Michel (2004): Geschichte der Gouvernementalität I: Sicherheit, Territorium, Bevölkerung. Frankfurt am Main: Suhrkamp Verlag.

Foucault, Michel (1997): “What is Critique?”. In: S. Lotringer \& L. Hochroch (Eds.): The Politics of Truth: Michel Foucault. New York: Semiotext, pp. 23-82.

Geis, Anna / Müller, Harald / Schörnig, Niklas (2010): “Liberale Demokratien und Krieg. Warum manche kämpfen und andere nicht. Ergebnisse einer vergleichenden Inhaltsanalyse von Parlamentsdebatten”. In: Zeitschrift für Internationale Beziehungen, 17 (2), pp. 171-202.

Meyer, Katrin (2009): “Kritik der Sicherheit Vom gouvernementalen Sicherheitsdenken zur Politik der 'geteilten Sorge”. In: traverse. Zeitschrift für Geschichte 16 (1), pp. 25-40.

Münkler, Herfried (2002): Die neuen Kriege. Reinbek bei Hamburg: Rowohlt Verlag.

Opitz, Sven (2008): “Zwischen Sicherheitsdispositiven und Securitization: Zur Analytik illiberaler Gouvernementalität”. In: Purtschert, Patricia / Meyer, Katrin / Winter, Yves (Eds.): Gouvernementalität und Sicherheit: zeitdiagnostische Beiträge im Anschluss an Foucault. Bielefeld: Transcript Verlag, pp. 201-228.

Winter, Yves (2008): “Gewaltökonomien und Unsicherheit. Zur Gouvernementalität der 'neuen Kriege’”. In: Purtschert, Patricia / Meyer, Katrin / Winter, Yves (Eds.): Gouvernementalität und Sicherheit: zeitdiagnostische Beiträge im Anschluss an Foucault. Bielefeld: Transcript Verlag, pp. 49-74.

Zelik, Raul (2009): Die kolumbianischen Paramilitärs - 'Regieren ohne Staat' oder terroristische Formen der Inneren Sicherheit. Münster: Verlag Westfälisches Dampfboot. 
